\title{
INOVASI PESANTREN RAMADHAN DALAM MENINGKATKAN KECERDASAN SPIRITUAL PESERTA DIDIK DI MASA PANDEMI COVID-19
}

\author{
Hisny Fajrussalam ${ }^{1 *}$, Koko Adya Winata ${ }^{2}$, Ihin Solihin ${ }^{3}$, Qiqi Yuliati Zaqiah ${ }^{4}$ \\ ${ }^{1}$ Universitas Pendidikan Indonesia, Indonesia \\ ${ }^{2,3,4}$ Program Pascasarjana UIN Sunan Gunung Djati Bandung, Indonesia \\ email: *11hfajrussalam@upi.edu, ${ }^{2}$ adyawinata@gmail.com, ${ }^{3}$ solihinihin64@gmail.com, \\ ${ }^{4}$ qiqi.yulianti@uinsgd.ac.id
}

\begin{abstract}
ABSTRAK
Penelitian dilatarbelakangi oleh krisis spiritualitas yang menimpa peserta didik. Peristiwa yang mencoreng nama baik peserta didik kerap terjadi di masyarakat. Pendidikan sebagai tempat mereka menimba ilmu perlu melakukan perubahan agar dapat menyelesaikan permasalahan tersebut. Di bulan Ramadhan tahun ini, sekolah-sekolah dipaksa untuk melakukan inovasi dalam pembelajaran kegiatan Ramdhan yang tidak mengurangi, bahkan menghilangkan esensi tujuan pembelajarannya. Penelitian ini bertujuan untuk untuk menggali inovasi pembelajaran pesantren Ramadhan dalam meningkatkan kecerdasan spiritualitas peserta didik di masa pandemi Covid-19. Penelitian dilakukan dengan menggunakan pendekatan kualitatif. Data yang bersifat kualitatif diperoleh dengan teknik wawancara tidak tatap muka dan studi dokumentasi terhadap pelaksanaan pembelajaran Pesantren Ramadhan di SMA Negeri 12 Kota Bandung dan SMA Negeri 21 Kota Bandung. Data kemudian dikompulasi dan dianalisis dengan menggunakan teknik analysis content. Hasil penelitian menunjukan bahwa inovasi pembelajaran pesantren Ramadhan yang diselenggarakan oleh SMA Negeri 12 Kota Bandung dan SMA Negeri 21 Kota Bandung yaitu: 1) Materi difokuskan pada pembahasan mengenai keimanan dan keshalehan sosial yang bertujuan untuk meningkatkan kecerdasan spiritual peserta didik; 2) Media yang digunakan dalam pembelajaran adalah media daring dengan berbagai platform; 3) Kegiatan diikuti tidak hanya oleh peserta didik muslim, akan tetapi juga non muslim; 4) Kegiatan terdokumentasi; dan 5) Peserta didik diarahkan untuk melakukan kegiatan sosial dengan memberikan bantuan bagi yang terdampak pandemi Covid-19.
\end{abstract}

Kata Kunci: Inovasi Pembelajaran, Pesantren Ramadhan, Kecerdasan Spiritual

\section{ABSTRACK}

Research is motivated by a crisis of spirituality that occurs in students. Events that tarnish the good name of students often occur in the community. Education as a place for them to gain knowledge needs to make changes in order to solve these problems. In the month of Ramadan this year, schools are forced to innovate in learning Ramadan activities that do not reduce, even eliminate the essence of learning objectives. This study aims to elaborate further about the learning innovations of the Pesantren Ramadhan in improving the intellectual intelligence of students during the Covid-19 pandemic. The study was conducted using a qualitative approach. Qualitative data were obtained by interviewing techniques without faceto-face interviews and documentation studies on the implementation of the Ramadhan Pesantren learning at SMA Negeri 12 Kota Bandung and SMA Negeri 21 Kota Bandung. The data is then compiled and analyzed using content analysis techniques. The results showed that the innovation of Ramadhan pesantren learning organized by SMA Negeri 12 Kota Bandung and SMA Negeri 21 Kota Bandung, namely: 1) The material is focused on discussion of faith and social piety aimed at enchancing learners' spiritual intelligence; 2) The media used in learning are online media with various platforms; 3) Activities are followed not only by Muslim students, but also non-Muslims; 4) Documented activities; and 5) Students are directed to carry out social activities by providing assistance to those affected by the Covid-19 pandemic.

Keywords: Learning Innovation, Pesantren Ramadhan, Spiritual Intelligence 


\section{PENDAHUluaN}

Salah satu kelebihan yang diberikan Allah swt. kepada manusia adalah fitrah (perasaan dan kemampuan) untuk mengenal dan melaksanakan ajaran Allah swt. Fitrah merupakan hal yang sangat mendasar. Ia dapat berkembang ke arah yang benar atau salah, berkualitas atau tidak, tergantung pada proses pendidikan yang diterimanya. Peran kecerdasan spiritual sangat dibutuhkan untuk mengembangkan fitrah yang ada pada manusia agar sesuai dengan ajaran agama Islam.

Kecerdasan spiritual mampu menggerakkan seseorang (red. peserta didik) untuk menjadi manusia lebih baik dengan tidak hanya mumpuni dalam keilmuan agama akan tetapi juga mumpuni dalam aksi keshalehan sosial [1]. Peserta didik yang memiliki kecerdasan spiritual mampu mempertahankan keharmonisan, keselarasan dalam kehidupannya sehari-hari serta bersikap humanis terhadap sesama [2]. Salah satu indikator peserta didik yang sehat secara spritual yaitu memiliki sikap tanggung jawab sosial, menunjukkan rasa kepedulian terhadap orang lain, memiliki sikap dan potensi ingin menolong ketika melihat orang lain kesulitan, memandang kehidupan secara realistis, dan memperoleh kebermaknaan spiritual melalui sikapnya yang prososial, yakni dengan lebih banyak memberi daripada menerima dan lebih mementingkan kesejahteraan orang banyak [3].

Dewasa ini, persoalan yang muncul adalah krisis spiritualitas yang terjadi pada diri peserta didik. Praktek dari krisis tersebut dapat dilihat dari peristiwa kriminalitas yang dilakukan peserta didik seperti halnya perampokan, tawuran antar sekolah, pemerkosaan, kecanduan narkoba, bahkan sampai pembunuhan. Hal ini disebabkan karena tidak adanya keseimbangan antara nilai-nilai keagamaan pada diri peserta didik dengan perkembangan teknologi yang semakin maju [4]. Untuk itu masalah akhlak atau moral peserta didik memerlukan perhatian khusus sehingga mampu membentengi mereka dari hal-hal yang tidak diinginkan.

Ternyata masalah tidak berhenti sampai di situ, masalah di dunia pendidikan pun tidak luput dari perhatian mengenai krisis spiritualitas. Faktanya, peserta didik secara terus-menerus mempelajari agama Islam dari segala aspek akan tetapi mereka belum secara penuh mengaplikasikannya dalam kehidupan sehari-hari. Selain itu peserta didik juga kurang mempunyai rasa tanggung jawab terhadap dirinya sendiri dan orang lain. Hal ini dapat dilihat dari kecenderungan peserta didik dalam melakukan sesuatu yang bertentangan dengan ajaran agama Islam [4].

Mengingat potensi yang dimiliki peserta didik harus dikembangkan agar mempunyai arahan dan tujuan dalam hidupnya, maka inovasi pembelajaran dalam rangka meningkatkan kecerdasan spiritual bagi peserta didik sangat diperlukan. Inovasi tersebut dimaksudkan agar peserta didik memiliki pemahaman yang utuh tentang ajaran Islam dan dapat mengaplikasikannya dengan benar dalam kehidupan sehari-hari. Peserta didik juga diharapkan menjadi manusia yang beriman dan bertaqwa kepada Allah swt. serta mampu mengaktualisasikan dirinya sesuai dengan ajaran dan norma agama Islam dengan kepribadian Islami dan berakhlakul karimah.

Penelitian mengenai upaya untuk meningkatkan kecerdasan spiritual pernah dilakukan oleh Haddar [5]. Haddar melakukan penelitiannya melalui kegiatan ekstrakurikuler yang menyimpulkan bahwa kegiatan ekstrakurikuler mampu menumbuhkan sikap peserta didik untuk bertindak positif yang berorientasi pada nilai-nilai Ketuhanan. Sementara itu, penelitian yang dilakukan penulis mencoba untuk menjelaskan upaya yang sama akan tetapi dengan konteks pembelajaran yang berbeda. Pembelajaran yang dimaksud adalah pembelajaran pesantren Ramadhan (Smartren). Selain itu, di masa pandemi Covid-19 saat ini, berbagai sekolah dipaksa untuk melakukan pembelajaran jarak jauh dengan model daring sebagai bentuk berupaya untuk melakukan inovasi pembelajaran pesantren Ramadhan. Sehingga tulisan kecil ini akan mencoba mengelaborasi lebih jauh mengenai inovasi pembelajaran pesantren Ramadhan di masa pandemi Covid-19. 


\section{METODE PENELITIAN}

Pendekatan penelitian yang digunakan adalah penelitian kualitatif. Sumber penelitian adalah kepala sekolah, guru dan siswa. Data yang bersifat kualitatif diperoleh dengan teknik wawancara tidak tatap muka dan studi dokumentasi terhadap pelaksanaan pembelajaran Pesantren Ramadhan di SMA Negeri 12 Kota Bandung dan SMA Negeri 21 Kota Bandung. Data kemudian dikompulasi dan dianalisis dengan menggunakan teknik analysis content.

\section{HASIL DAN PEMBAHASAN}

\subsection{Urgensi Inovasi Pembelajaran Pesantren Ramadhan (Smartren) di Masa Pandemi Covid-19}

Pendidikan memiliki peran penting dalam keberhasilan pembangunan dan peradaban suatu bangsa. Negara-negara di dunia dapat dikategorikan maju karena sistem pendidikannya yang unggul. Kita ambil saja misalnya Amerika Serikat. Negara Amerika Serikat tidak diragukan lagi dengan prestasi ekonomi dan militer yang dapat ditiru oleh negara-negara lainnya di dunia. Namun kualitas pendidikan di Amerika Serikat belum dapat disejajarkan dengan negara-negara lainnya. Oleh karenanya, pendidikan merupakan sistem penggerak yang menentukan peradaban dan kemajuan suatu bangsa. Mustahil sebuah negara akan maju kalau generasinya tidak dipersiapkan dengan mutu pendidikan yang unggul. Tanpa pendidikan yang unggul manusia tidak akan maju dan tidak akan memiliki peradaban yang baik. Manusia akan tetap kerdil, ketinggalan yang pada akhirnya akan tergilas kekuatan dan dikalahkan dengan persaingan dan tantangan zaman. Kehidupan manusia tidak akan mengalami kemajuan karena manusia yang tidak berpendidikan unggul tidak akan memiliki kreatifitas sebagaimana halnya orang yang terdidik. Oleh karena itu, upaya peningkatan mutu pendidikan merupakan hal yang tidak dapat ditawar lagi dalam rangka meningkatkan mutu sumber daya bangsa Indonesia. Pendidikan merupakan proses sistematis untuk meningkatkan martabat manusia secara holistik [6]. Untuk melahirkan pendidikan yang unggul maka diperlukan sebuah inovasi model pembelajaran yang akan membuat gairah peserta didik dalam proses pembelajaran. Motivasi dan minat peserta didik di dalam proses pembelajaran sangat dipengaruhi oleh model, dan strategi pembelajaran yang diterapkan oleh guru. Model pembelajaran adalah suatu pola yang digunakan sebagai pedoman dalam merencanakan pembelajaran di kelas. Model pembelajaran mengacu pada pendekatan pembelajaran yang akan digunakan, termasuk di dalamnya tujuan-tujuan pengajaran, tahap-tahap dalam kegiatan pembelajaran, lingkungan pembelajaran, dan pengelolaan kelas [7].

Inovasi pembelajaran pesantren Ramadhan di masa Covid-19 menggunakan model pembelajaran daring. Secara lebih spesifik, pembelajaran pesantren Ramadhan di masa pandemi Covid-19 ini memerlukan perlakuan khusus karena sistem pembelajaran dilaksanakan daring. Oleh karenanya, diperlukan adanya inovasi sehingga tujuan pembelajaran dapat tercapai. Adanya pandemi Covid-19 telah menyadarkan seluruh pihak di lingkungan pendidikan baik guru dan peserta didik akan pentingnya penguasaan terhadap teknologi komunikasi diantarnya internet. Sebelum terjadinya pandemi Covid-19, proses pembelajaran dilakukan secara konvensional artinya tatap muka langsung. Ketika wabah ini mengglobal dan corona telah menjadi virus yang mematikan, maka proses pembelajaran pun tidak dilakukan dengan metode konvensional melainkan dengan model pembelajaran daring (online). Perubahan proses pembelajaran dari konvensional ke model pembelajaran daring dapat menjadi solusi agar proses pembelajaran tetap berlangsung sebagaimana mestinya. Dalam model pembelajaran daring setiap guru dan peserta didik dituntut untuk menguasi teknologi ilmu computer (TIK). Penguasaan terhadap teknologi ilmu komputer menjadi syarat yang paling utama dalam pelaksaan pembelajaran daring. Guru dan peserta didik berkomunikasi melalui media web dengan berbagai varian teknologi yang tersedia.

Karakteristik pembelajaran daring, antara lain 1) Materi ajar disajikan dalam bentuk teks, grafik dan berbagai elemen multimedia; 2) Komunikasi dilakukan secara serentak dan tak serentak seperti video conferencing, chats rooms, atau discussion forums; 3) Digunakan untuk belajar pada waktu dan tempat maya; 4) Dapat digunakan berbagai elemen belajar berbasis CDROM, untuk meningkatkan komunikasi belajar; 5) Materi ajar relatif mudah diperbaharui; 6) Meningkatkan interaksi antara siswa dan fasilitator; dan 7) Memungkinkan bentuk komunikasi 
belajar formal dan informal; 8) Dapat menggunakan ragam sumber belajar yang luas di internet [8].

\subsection{Inovasi Pembelajaran Pesantren Ramadhan (Smartren) untuk Meningkatkan Kecerdasan Spiritualitas Peserta Didik di SMA Negeri 12 Kota Bandung dan SMA Negeri 21 Kota Bandung}

Kegiatan pembelajaran pesanten Ramadhan yang dilaksanakan oleh SMA Negeri 12 Kota Bandung dan SMA Negeri 21 Kota Bandung merupakan kegiatan berdasarkan Surat Edaran Dinas Pendidikan No. 443/5037-Set.Disdik tanggal 23 April 2020. Adapun tujuan dilaksanakan kegiatan ini yaitu, pertama menumbuhkan nilai-nilai luhur Ramadhan dan penguatan pendidikan karakter dalam kondisi Pandemi Covid-19. Kedua, menambah dan memperluas wawasan keislaman. Ketiga, meningkatkan amaliah di bulan Ramadhan yang dilaksanakan secara terencana sesuai situasi, kondisi, dan potensi masing-masing satuan pendidikan. Keempat, menerapkan pengamalan ajaran Islam dalam kehidupan sehari-hari berupa bimbingan, arahan, pelatihan, pembiasaan yang dilakukan secara bersama-sama dan berkesinambungan antara pihak sekolah dan orang tua.

Pembelajaran pesantren Ramadhan dilaksanakan mulai tanggal 27 April sampai dengan 20 Mei 2020 yang diikuti oleh kelas X dan kelas XI yang terdiri dari peserta didik muslim dan non muslim. Adapun jumlah peserta didik yang mengikuti pembelajaran pesantren Ramadhan dapat dilihat pada tabel berikut:

Tabel 1. Sebaran Data Peserta Didik yang Mengikuti Pembelajaran Pesantren Ramadhan

\begin{tabular}{l|c|c|c|c}
\hline & \multicolumn{3}{|c}{ Kelas X } & \multicolumn{2}{c}{ Kelas XI } \\
\cline { 2 - 5 } & Muslim & Non Muslim & Muslim & Non Muslim \\
\hline $\begin{array}{l}\text { SMA Negeri 12 } \\
\text { Kota Bandung }\end{array}$ & 323 & 19 & 330 & 25 \\
\hline $\begin{array}{l}\text { SMA Negeri 21 } \\
\text { Kota Bandung }\end{array}$ & 302 & 16 & 371 & 23 \\
\hline
\end{tabular}

Berdasarkan data di atas, dapat dilihat bahwa keterlibatan peserta didik non muslim dalam kegiatan pesantren Ramadhan tidak lain untuk memberikan perlakuan yang sama bagi mereka yang tidak memeluk agama Islam untuk memperoleh hak yang sama dengan peserta didik muslim. Hal ini merupakan sikap inklusif yang dilakukan oleh SMA Negeri 12 Kota Bandung dan SMA Negeri 21 Kota Bandung, sehingga potensi konflik multikultural dapat dieliminir. Sikap multikultural ini harus dikembangkan dan dibina karena merupakan kekayaan bangsa yang tak ternilai harganya [9]. Sebaliknya apabila sikap multikultural dengan menghormati keberagaman ini tidak dimanfaatkan, dan dibina secara benar akan berkembang menjadi sesuatu yang menakutkan. Hal ini bukan tanpa sebab, masyarakat yang memiliki keragaman berpotensi besar mengandung resiko konflik di antara kelompok-kelompok yang berbeda, baik secara etnisitas maupun faktor perbedaan lainnya. Salah satu sumber konflik yang rentan muncul di tengah-tengah masyarakat yang memiliki keragaman adalah konflik yang bersumber dari perbedaan agama. Studi yang dilakukan Centre of Strategic and International Studies (CSIS) pada tahun 2012, menyatakan bahwa toleransi beragama orang Indonesia tergolong rendah. Dalam survei CSIS, sebanyak 59,5 persen responden tidak berkeberatan bertetangga dengan orang beragama lain. Sekitar 33,7 persen lainnya menjawab sebaliknya. Penelitian ini dilakukan pada Februari 2012 di 23 provinsi di Indonesia dan melibatkan 2.213 responden. Saat ditanya soal pembangunan rumah ibadah agama lain di lingkungannya, sebanyak 68,2 persen responden menyatakan lebih baik hal itu tidak dilakukan. Hanya 22,1 persen yang tidak berkeberatan. Kabar baiknya, hasil penelitian menunjukkan bahwa Indeks Toleransi antarumat Beragama di Kota Bandung sebesar 3,82 termasuk dalam kategori "Tinggi”, yang mengindikasikan bahwa interaksi sosial antarumat beragama di Kota Bandung telah berlangsung secara baik dan berada dalam batas-batas jarak sosial yang wajar. Kemungkinan konflik umumnya dipicu oleh perizinan pembangunan rumah ibadat yang berada dalam ranah kewenangan pemerintah, sehingga hal ini penting untuk dibenahi dalam rangka meningkatkan capaian Indeks Toleransi di Kota Bandung 
[10]. Sementara itu, kehadiran Pancasila sebagai pemersatu ideologi bangsa adalah sebuah solusi dari adanya konflik yang terjadi antar golongan nasionalis dan agama, Pancasila telah mampu menunjukan fungsinya sebagai pemersatu bangsa Indonesia yang majemuk, heterogen, multikultural [11]. Oleh karena itu, pembelajaran pesantren Ramadhan di SMA Negeri 12 Kota Bandung dan SMA Negeri 21 Kota Bandung merupakan langkah konkret pendidikan yang berbasis multikulturalisme sebagai bagian dari upaya meningkatkan kecerdasan spiritualitas.

Sementara itu, inovasi yang dilakukan oleh SMA Negeri 12 Kota Bandung dan SMA Negeri 21 Kota Bandung dengan adanya program pesantren Ramadhan adalah dengan melakukan design terhadap materi pembelajaran sehingga menjadi kebutuhan dasar peserta didik dalam menghadapi pandemi Covid-19. Uniknya, terdapat kesamaan materi yang diajarkan oleh SMA Negeri 12 Kota Bandung dan SMA Negeri 21 Kota Bandung. Adapun sebaran materi dan jumlah guru dapat dilihat pada tabel-tabel berikut:

Tabel 2. Sebaran Materi Pembelajaran Pesantren Ramadhan

\begin{tabular}{|c|c|c|}
\hline & Peserta Didik Muslim & Peserta Didik Non Muslim \\
\hline Materi & $\begin{array}{l}\text { Akidah, akhlak, Al- } \\
\text { Qur'an, hadis, fiqh, dan } \\
\text { Islam rahmatan lil alamin, } \\
\text { dan sejarah kebudayaan } \\
\text { Islam }\end{array}$ & $\begin{array}{l}\text { Kehidupan Yesus, Roh Kudus, } \\
\text { Bacaan Injil dari Yohanes, dan } \\
\text { Renungan harian, HAM dalam } \\
\text { ajaran gereja, dan budaya kekerasan } \\
\text { vs budaya kasih }\end{array}$ \\
\hline
\end{tabular}

Tabel 3. Sebaran Guru Pelajaran Agama

\begin{tabular}{l|c|c}
\hline & Guru Muslim & Guru Non Muslim \\
\hline SMA Negeri 12 Kota Bandung & 2 Orang & 2 Orang \\
\hline SMA Negeri 21 Kota Bandung & 3 Orang & 2 Orang \\
\hline
\end{tabular}

Tabel 2. menggambarkan bahwa materi yang diajarkan selama kegiatan pesantren Ramadhan di SMA Negeri 12 Kota Bandung dan SMA Negeri 21 Kota Bandung relatif sama dan berfokus pada peningkatan keimanan dan ketaqwaan masing-masing peserta didik serta keshalihan sosial sebagai perwujudan keduanya dalam kehidupan sehari-hari. Materi AqidahAkhlak bagi peserta didik muslim bertujuan untuk membangun kembali sikap kehambaan kepada Tuhan, sedangkan materi Al-Qur'an-Hadis betujuan untuk membiasakan diri agar peserta didik muslim senantiasa beramal dengan kalamullah dan sunnah Nabi. Hasil penelitian menunjukan bahwa terdapat pengaruh signifikan pembelajaran Aqidah-Akhlak terhadap perilaku peserta didik [12]. Sementara itu, materi fiqh dimasukkan ke dalam pembelajaran tidak lain untuk memberikan penguatan keilmuan terhadap pelaksanaan ibadah, khususnya di bulan puasa. Sejalan dengan hal tersebut, penelitian yang dilakukan oleh Agustiningrum menunjukan bahwa pembelajaran fiqh mampu meningkatkan pemahaman peserta didik mengenai praktek ibadah sehari-hari [13]. Materi Islam rahmatan lil alamin dan sejarah kebudayaan Islam merupakan materi yang mengajarkan untuk senantiasa menumbukan sikap kebersamaan dengan tidak memandang agama, suku, dan ras dengan memberikan bantuan kepada masyarakat yang terdampak pandemi Covid-19 dengan jalan berinfaq dan bersodaqoh sebagaimana sejarah para Nabi, Rasul dan ulama memberikan bantuan bagi mereka yang membutuhkan. Gagasan Islam rahmatan lil alamin bersifat inklusif. Islam sebagai agama dan Nabi Muhammad sebagai pembawanya, sama-sama hadir untuk membawa kedamaian, kelembutan dan kebaikan tertinggi [14].

Materi pembelajaran Ramadhan bagi peserta didik non muslim pun memiliki fokus tujuan yang sama, yakni dengan meningkatkan keimanan kepada Tuhan dan keshalehan sosial. Hal ini diwujudkan dengan materi pembelajaran yang membahas kehidupan Yesus, Roh Kudus, bacaan dari Yohanes, dan renungan Harian. Penanaman sikap untuk saling menghormati sesama, inklusivisme, memberikan batuan bagi yang membutuhkan, menerapkan dan mengamalkan ajaran dalam kehidupan sehari-hari dalam rangka membentuk mental spiritual yang tangguh, kokoh, dan mampu menghadapi tantangan-tantangan negatif, baik yang datang dari dirinya pribadi maupun dari luar dirinya serta mengambil hikmah dari fenomena pandemi Covid-19 yang 
terjadi saat ini dan bisa lebih meningkatkan ketaqwaan kepada Tuhan juga terlihat dengan adanya materi HAM dalam ajaran gereja dan budaya kekerasan vs budaya kasih.

Pembelajaran pesantren Ramadhan tidak hanya dilakukan dengan pemberian materi bagi peserta didik, akan tetapi kegiatan yang berhubungan dengan keagamaan masing-masing peserta didik juga dijadikan pembelajaran wajib. Bagi peserta didik muslim kegiatan yang dimaksud adalah shalat 5 waktu, shalat tawarih dan tadarus Al-Qur'an. Sementara bagi peserta didik non muslim kegiatan yang dilakukan adalah membaca Injil dan mendengarkan renungan dari aplikasi E-Katolik.

Adapun media yang digunakan dalam proses pembelajaran pesantren Ramdhan di SMA Negeri 12 Kota Bandung dan SMA Negeri 21 Kota Bandung adalah dengan memanfaatkan berbagai platform, berupa Google Classroom, media penyiaran live (video yang dibuat oleh guru Agama, RRI, TVRI, IGTV, AGPAII Chanel, Youtube), Whatsapp, Line, dan Google Form.
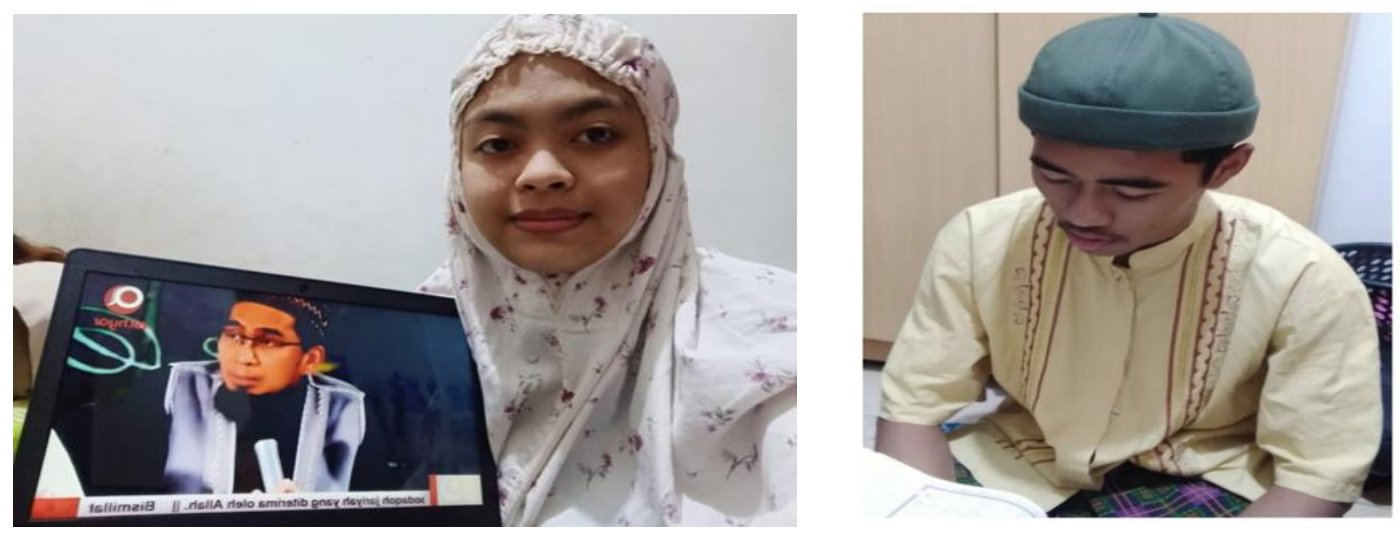

Gambar 1. Kegiatan Pembelajaran Pesantren Ramadhan

Media daring yang digunakan oleh SMA Negeri 12 Kota Bandung dan SMA Negeri 21 Kota Bandung dalam pembelajaran pesantren Ramadhan merupakan langkah yang baik, karena hasil penelitian menunjukan bahwa pembelajaran daring dapat meningkatkan kemampuan pemahaman peserta didik [15] dan membangun komunitas pembelajaran [16].

Pembelajaran pesantren Ramadhan yang dilakukan oleh SMA Negeri 12 Kota Bandung dan SMA Negeri 21 Kota Bandung pun tidak hanya berupa asupan materi saja, melainkan juga pembelajaran diarahkan kepada aksi sosial di masyarakat sebagai bentuk kepedulian bagi masyarakat yang terdampak pandemi Covid-19. Untuk menanamkan kepedulian sosial, langkah yang dapat ditempuh oleh guru adalah dengan menggunakan strategi verbal dan non verbal. Strategi verbal diberikan kepada peserta didik melalui pemberian motivasi, nasihat, cerita, teguran, hukuman, dan pujian, sedangkan cara non verbal melalui pembiasaan perilaku, dan teladan [17].
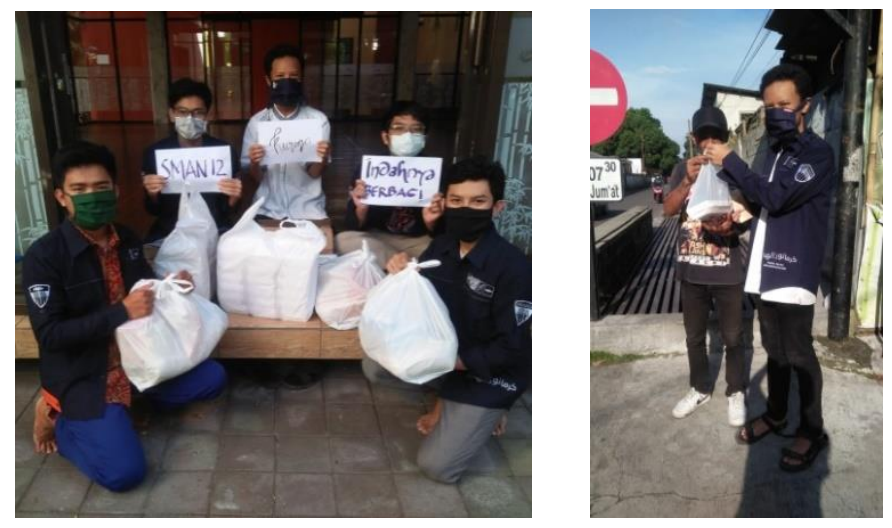

Gambar 2. Kegiatan Aksi Sosial Pesantren Ramadhan 
Dari pemaparan yang di atas, inovasi yang dilakukan oleh SMA Negeri 12 Kota Bandung dan SMA Negeri 21 Kota Bandung dalam pembelajaran pesantren Ramadhan (Smartren) adalah sebagaimana gambar berikut.

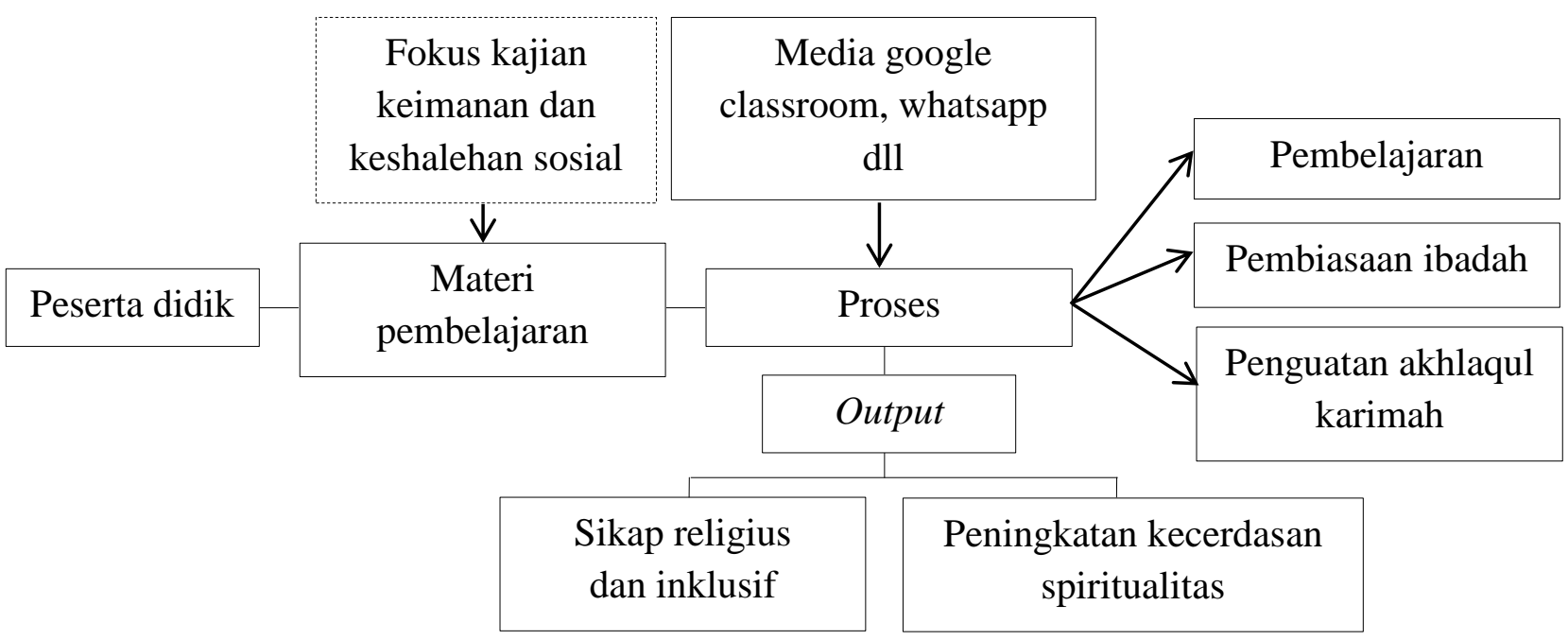

Gambar 3. Inovasi Pembelajaran Pesantren Ramadhan

Gambar 3. menunjukan bahwa pembelajaran pesantren Ramadhan yang diselenggarakan oleh SMA Negeri 12 Kota Bandung dan SMA Negeri 21 Kota Bandung merupakan salah satu inovasi pembelajaran untuk lebih memahami, menghayati dan melaksanakan ibadah dengan baik di bulan suci Ramadhan serta menumbuhkan sikap saling menghormati dengan yang berbeda agama dan memperdalam kepedulian bagi mereka yang terdampak pandemi Covid-19 sehingga melahirkan sikap kehambaan, multikultralisme dan meningkatkan kecerdasan spiritualitas dalam diri peserta didik.

\subsection{Faktor Pendukung dan Penghambat Pelaksanaan Pembelajaran Pesantren Ramadhan}

Sebuah kegiatan akan terlakasana dengan baik manakala mendapat faktor pendukung yang realistis, baik dari internal maupun external, termasuk penyelenggaraan pesantren Ramadhan pada masa pandemi Covid-19 SMA Negeri 12 Kota Bandung dan SMA Negeri 21 Kota Bandung.

Faktor pendukung yang muncul dari dalam, diantaranya:

a. Visi sekolah yang mengamanatkan untuk mewujudkan peserta didik yang ungggul, kompetitif, berakhlak mulia dan berbudaya lingkungan yang berbasis agamis.

b. Sumber daya yang memadai. SMA Negeri 12 Kota Bandung dan SMA Negeri 21 Kota Bandung memiliki pendidik agama yang kompeten dan masih muda, baik yang muslim maupun non muslim. Mereka memiliki sikap kreatif dan inovatif sehingga mampu adaptif dengan kondisi yang yang berkembang saat ini.

c. Fasilitas yang tersedia disekolah, seperti internet, laborarium komputer, VC, audio dan lain sebagainnya yang menjadi pendukung terlaksananya inovasi dalam pembelajaran.

d. Pembelajaran e-learning dengan penggunaan intranet dan extranet sudah terbiasa dilakukan dalam pembelajaran regular sehari-hari.

e. Pengembangan bakat dan minat peserta didik difasilitasi dalam kegiatan intra maupun extrakurikuler, sehingga terdapat 27 cabang kegiatan extra-kurikuler.

Adapun faktor pendukung yang berasal dari luar, diantaranya:

a. Peraturan Presiden Nomor 87 Tahun 2017 tentang Pendidikan Penguatan Karakter.

b. Peraturan Menteri Pendidikan dan Kebudayaan Nomor 20 Tahun 2018 tentang Penguatan Pendidikan Karakter pada Satuan Pendidikan Formal

c. Surat Edaran Mendikbud RI Nomor 4 Tahun 2020 tanggal 24 Maret 2020 tentang Pelaksanan Kebijakan Pendidikan dalam Masa Darurat Penyebaran Corona Virus Disesase (Covid-19). 
d. Surat Edaran Menteri Agama RI Nomor SE.6 Tahun 2020 Tanggal 6 April 2020 tentang Panduan Ibadah Ramadhan dan Idul Fitri 1 Syawal 1441 H di tengah Pandemi Wabah Covid19.

e. Keputusan Gubernur Jawa Barat No. 443/Kep.189-Hukham/2020 tanggal 19 Maret 2020 tentang Status Keadaan Tertentu Darurat Bencana Wabah Penyakit Akibat Corona Virus Disease 19 di Jawa Barat.

f. Surat Kepala Dinas Pendidikan Provinsi Jawa Barat Nomor 443 / 4181-Set Disdik Tanggal 9 April 2020 tentang Perpanjangan Waktu Pelaksanaan PBM di Rumah dan Informasi Kegiatan Akademik Tahun Pelajaran 2019/2020.

g. Surat Edaran Dinas Pendidikan no 443/5037-Set.Disdik tanggal 23 April 2020.

h. Perkembangan ilmu pengetahuan dan teknologi yang pesat, memberikan kemudahan dan menyediakan berbagai fasilitas aplikasi elektronik yang dapat digunakan untuk dapat terselenggarannya kegiatan keagamaan, seperti zoom metting, google meet, youtube, google clasrooom, e-know, Whatsapp dan lainnya.

Di sisi lain, tidak selamanya sebuah kegitan dapat berjalan mulus dan baik, ketika dilaksanakan ternyata ada faktor penghambat yang mengakibatkan tersendatnya kegitan tersebut, sehingga membutuhkan kreasi dan inovasi dalam menyelesaikan program tersebut, termasuk dalam penyelenggaraan pesantren Ramadhan pada masa pandemi Covid-19, diantaranya:

a. Peserta didik di rumah memiliki keterbatasan kuota internet, sehingga sangat terbatas untuk melakukan komunikasi.

b. Pemakaian aplikasi yang sudah disiapkan oleh guru tidak begitu maksimal, sehingga tujuan tidak dapat tercapai $100 \%$.

c. Keterbatasan untuk monitoring peserta didik, karena guru tidak dapat menggunakan alat-alat deteksi maksimal terhadap kondisi peserta didik di rumah, walaupun absensi dan kiriman bukti photo kegitan di rumah disampaikan melalu aplikasi dan link yang sudah cukup baik.

d. Motivasi, kejujuran dan kedisiplinan peserta didik yang kurang karena merasa tidak begitu diawasi dan adanya kebebasan maka proses pembelajaran pun tidak begitu maksimal.

e. Keterbatasan daya dukung dari orang tua terhadap keterlaksanaan program tersebut sangat terbatas, sehingga membutuhkan ektra inovasi dan keuletan dari guru pengampunya.

f. Pembelajaran online dengan cara jarak jauh yang harus terlaksana dengan sangat mendadak, sehingga sudah dapat diprediksi upaya yang dapat dilakukan tanpa sebuah perencanaan matang, yang ada adalah hanya upaya inovasi dan kreatifivitas yang terbatas. Akan tetapi yang penting adalah bagaimana pembelajaran dapat dilaksanakan dengan dilakukan perbaikan secara gradual sambil berjalan.

\subsection{Solusi yang Ditawarkan}

Dari pembahasan mengenai faktor penghambat pelaksanaan pembelajaran pesantren Ramadhan di SMA Negeri 12 Kota Bandung dan SMA Negeri 21 Kota Bandung, maka diperlukan adanya solusi agar pembelajaran yang dilakukan di kemudian hari dengan kondisi yang sama dapat berjalan dengan baik. Jalan keluar yang dapat ditempuh adalah:

a. Pemberian kuota internet bagi peserta didik sehingga pembelajaran daring tidak menjadi hambatan bagi peserta didik yang keterbatasan kuota internet.

b. Tutorial dan pelatihan mengenai pembelajaran berbasis aplikasi yang disiapkan guru atau sekolah dapat menyusun manual user mengenai petunjuk pelaksanaan aplikasi tersebut.

c. Dukungan dari orang tua untuk dapat melakukan monitoring terhadap proses pelaksanaan pembelajaran daring.

d. Penanaman sikap jujur dan disiplin melalui pembiasaan yang dilakukan di sekolah. Pembiasaan yang dimaksud adalah dengan mengoptimalkan pelaksanaan upacara bendera setiap hari senin, pembiasaan membuang sampah pada tempatnya, dan datang tepat waktu ke sekolah.

e. Sosialisasi pembelajaran daring dengan orang tua peserta didik yang diharapkan dapat memberikan dukungan orang tua terhadap kesuksesan pelaksaan pembelajaran tersebut.

f. Sekolah harus senantiasa siap terhadap kondisi dan situasi yang terjadi di dunia pendidikan. Pembuatan rencana A dan rencana B perlu disiapkan sedini mungkin untuk mengakomodir hal-hal yang tidak dapat diprediksi. 


\section{KESIMPULAN}

Pembelajaran pesantren Ramadhan di SMA Negeri 12 Kota Bandung dan SMA Negeri 21 Kota Bandung dilakukan dengan membuat langkah inovatif guna meningkatkan kecerdasan spiritualitas peserta didik. Langkah ini ditempuh sejalan dengan penyebaran pandemi Covid-19. Hasil yang diperoleh dari penelitian adalah: 1) Materi difokuskan pada pembahasan mengenai keimanan dan keshalehan sosial yang bertujuan untuk meningkatkan kecerdasan spiritual peserta didik; 2) Media yang digunakan dalam pembelajaran adalah media daring dengan berbagai platform; 3) Kegiatan diikuti tidak hanya oleh peserta didik muslim, akan tetapi juga non muslim; 4) Kegiatan terdokumentasi; dan 5) Peserta didik diarahkan untuk melakukan kegiatan sosial dengan memberikan bantuan bagi yang terdampak pandemi Covid-19; 6) Faktor pendukung dan penghambat pelaksanaan kegiatan pesantren Ramadhan terdiri dari faktor internal dan eksternal.

\section{DAFTAR PUSTAKA}

[1] R. Wahyuni, M. D. Mayangsari, dan R. Fauzia, "Hubungan Kecerdasan Spiritual dengan Perilaku Prososial pada Perawat di Rumah Sakit Islam Banjarmasin," J. Ecopsy, vol. 3, no. 3, hlm. 140-143, Jan 2017, doi: 10.20527/ecopsy.v3i3.2663.

[2] A. Wahab dan Umiarso, Kepemimpinan Pendidikan Dan Kecerdasan Spritual. Yogyakarta: Ar-Ruzz Media, 2011.

[3] T. Safaria, Spritual Intellegency Metode Pengembangan Kecerdasan Spritual Anak. Yogyakarta: Graha Ilmu, 2007.

[4] L. H. Utami, "Pengembangan Kecerdasan Spiritual Siswa di SD Islam Tompokersan Lumajang," Psympathic J. Ilm. Psikol., vol. 2, no. 1, hlm. 63-78, Feb 2016, doi: 10.15575/psy.v2i1.448.

[5] G. A. Haddar, "Upaya Pengembangan Kecerdasan Spiritual Siswa Melalui Kegiatan Ekstrakurikuler Rohani Islam di SMP Yapan Indonesia, Depok," J. Pendas Mahakam, vol. 1, no. 1, hlm. 42-53, 2016, [Daring]. Tersedia pada: https://jurnal.fkipuwgm.ac.id/index.php/pendasmahakam/article/view/38.

[6] H. Widodo, "Potret Pendidikan di Indonesia dan Kesiapannya dalam Menghadapi Masyarakat Ekonomi Asia (MEA)," Cendekia J. Kependidikan Dan Kemasyarakatan, vol. 13, no. 2, hlm. 293-307, Jul 2015, doi: 10.21154/cendekia.v13i2.250.

[7] Trianto, Model Pembelajaran Terpadu. Jakarta: Bumi Pustaka, 2010.

[8] M. I. Mustofa, M. Chodzirin, dan L. Sayekti, "Formulasi Model Perkuliahan Daring Sebagai Upaya Menekan Disparitas Kualitas Perguruan Tinggi (Studi terhadap Website pditt.belajar.kemdikbud.go.id)," Walisongo J. Inf. Technol., vol. 1, no. 2, hlm. 151-160, 2019, doi: 10.21580/wjit.2019.1.2.4067.

[9] Kuswaya Wihardit, "Pendidikan Multikultural: Suatu Konsep, Pendekatan dan Solusi," J. Pendidik., vol. 11, no. 2, hlm. 96-105, Agu 2010, doi: 10.33830/jp.v11i2.561.2010.

[10] R. Hermawati, C. Paskarina, dan N. Runiawati, "Toleransi Antar Umat Beragama di Kota Bandung," Indones. J. Anthropol., vol. 1, no. 2, Mar 2017, doi: 10.24198/umbara.v1i2.10341.

[11] A. M. A. Shofa, "Memaknai Kembali Multikulturalisme Indonesia dalam Bingkai Pancasila," J. Pancasila Dan Kewarganegaraan, vol. 1, no. 1, hlm. 34-41, Jul 2016.

[12] S. F. Yanti, "Pengaruh Pembelajaran Aqidah Akhlak terhadap Perilaku Siswa di Madrasah Aliyah Negeri Kampar Timur," J. Online Mhs. Fak. Ilmu Sos. Dan Ilmu Polit., vol. 4, no. 1, hlm. 1-12, 2017, [Daring]. Tersedia pada: https://jom.unri.ac.id/index.php/JOMFSIP/article/view/13436.

[13] A. Silvi, "Pengaruh Pembelajaran Fiqih Thaharah terhadap Kemampuan Praktik Bersuci Siswa SMP Plus Arroudhoh Sedati," Skripsi, Universitas Islam Negeri Sunan Ampel Surabaya, Surabaya, 2018.

[14] M. M. Rasyid, "Islam Rahmatan Lil Alamin Perspektif KH. Hasyim Muzadi," Epistemé J. Pengemb. Ilmu Keislam., vol. 11, no. 1, hlm. 93-116, Jun 2016, doi: 10.21274/epis.2016.11.1.93-116.

[15] N. L. Khusniyah dan L. Hakim, "Efektivitas Pembelajaran Berbasis Daring: Sebuah Bukti pada Pembelajaran Bahasa Inggris," J. Tatsqif, vol. 17, no. 1, hlm. 19-33, Jul 2019, doi: 10.20414/jtq.v17i1.667. 
[16] S. A.N., Bayu, Rani, dan Mediawati, "Persepsi Siswa dalam Pengaruh Studi Daring Learning terhadap Minat Belajar IPA," Scaffolding J. Pendidik. Islam Dan Multikulturalisme, vol. 1, no. 2, hlm. 30-38, Desember 2019, [Daring]. Tersedia pada: https://ejournal.insuriponorogo.ac.id/index.php/scaffolding/article/view/117.

[17] A. Admizal dan E. Fitri, "Pendidikan Nilai Kepedulian Sosial Pada Siswa Kelas V Di Sekolah Dasar," J. Gentala Pendidik. Dasar, vol. 3, no. 1, hlm. 163-180, Jun 2018, doi: 10.22437/gentala.v3i1.6778. 